\title{
MORPHOLOGICAL VARIATIONS OF TERRESTRIAL ORCHID THELYMITRA JAVANICA BLUME (ORCHIDACEAE: ORCHIDOIDEAE) IN MOUNT ARJUNO, LAWU, AND SUMBING, JAVA - INDONESIA
}

\author{
I Made Saka Wijaya ${ }^{1}$, Budi Setiadi Daryono ${ }^{2} \&$ Purnomo $^{3}$ \\ ${ }^{1)}$ Postgraduated Student Faculty of Biology, Universitas Gadjah Mada, Yogyakarta 55281, Indonesia \\ Email: saka.wijaya@mail.ugm.ac.id / imsakawijaya@gmail.com \\ ${ }^{2)}$ Laboratory of Genetics and Breeding, Faculty of Biology, Universitas Gadjah Mada, \\ Yogyakarta 55281, Indonesia \\ Email: bs.daryono@mail.ugm.ac.id \\ ${ }^{3)}$ Laboratory of Plant Systematics, Faculty of Biology, Universitas Gadjah Mada, \\ Yogyakarta 55281, Indonesia \\ Email: nomo@ugm.ac.id
}

I Made Saka Wijaya, Budi Setiadi Daryono \& Purnomo. 2018. Variasi Morfologi Anggrek Tanah Thelymitra javanica Blume (Orchidaceae: Orchidoideae) di G. Arjuno, G. Lawu dan G. Sumbing, Jawa-Indonesia. Floribunda 6(1): 22-31. - Tujuan kajian ini adalah untuk mengetahui variasi morfologi dan kekerabatan fenetik dari $T$. javanica dari ketiga gunung tersebut. Tiga belas sampel dikoleksi dari sepanjang jalur pendakian. Pengamatan morfologi dilakukan terhadap organ akar, umbi, daun, tangkai perbungaan, braktea, bunga, buah dan biji. Dendrogram dibangun dengan metoda kluster UPGMA dengan algoritma "Percent's Similarity". Sedangkan analisis PCA dilakukan dengan algoritma "Euclidean Distance" menggunakan perangkat lunak MVSP v.3.1. Hasil studi menunjukkan bahwa variasi morfologi jenis $T$. javanica tergolong plastis dalam hal ukuran dan warna, terutama warna tangkai perbungaan, mahkota, labelum, ovarium dan rangka ovarium, yang dapat digunakan untuk membedakan populasi atau ekotipe.

Kata kunci: Ekotipe, Orchidaceae, fenetik, plastisitas, Thelymitra javanica.

I Made Saka Wijaya, Budi Setiadi Daryono \& Purnomo. 2018. Morphological Variations of Terrestrial Orchid Thelymitra javanica Blume (Orchidaceae: Orchidoideae) in Mount Arjuno, Lawu, and Sumbing, JavaIndonesia. Floribunda 6(1): 22-31. - The aims of this study were to observe morphological variations and phenetic relationships of $T$. javanica from the three mountains. Thirteen samples were colected along the tracking routes, morphological observation was based on character of root, tuber, leaf, peduncle, floral bract, flower, fruit, and seed. The data were compile descriptively to identify variations that subsequently scored. Dendrogram were constructed by UPGMA clastering method with Percent's Similarity algorithm, while Principal Component Analysis was done with Euclidean Distance algorithm using MVSP v.3.1. software. The result shows that morphological variations of $T$. javanica is found to be plastis for size and color, especially color of peduncle, petals, labellum, ovary, and ovary ribs that can be used to separate distinct population or ecotype.

Keywords: Ecotype, Orchidaceae, phenetic, plasticity, Thelymitra javanica

Indonesia has part of Sundaland and Wallacean as the center of biodiversity with some conservation priorities and high number of endemic plants (Myers et al. 2000). One of the plant family that has high endemicity is orchids (Orchidaceae), that not only adaptive, but also showing great evolutionary traits especially from the floral characters (Dressler 1993; Kindlman \& Jersakova 2005). Orchids are cosmopolite plants, distributed from the sea shore to the mountain (Dressler 1993; Brown et al. 2008; Roberts \& Dixon 2008; Swartz \& Dixon 2009). Some orchid species might grow at the top of the mountain in a distinct habitat such as volcano.
Thelymitra is a genus of terestrial orchid that distributed mainly in Australia with over 110 species (Jeanes 2013). Most species are distributed in lowland area (Edens-Meier et al. 2013; Jeanes 2013; Edens-Meier \& Bernhardt 2014), while $T$. javanica that occur in Indonesia is occupied highland. This species grow at the altitude 1,4003,300 meters above sea level ( $\mathrm{m}$ asl), dominantly at $>2,000 \mathrm{~m}$ asl, with high light intensity and sandy soils (Backer \& Bakhuizen v.d. Brink 1968). T. javanica also tolerates soil with high content of sulphur that allow the plant to grow near the peak of active volcano (Comber 1990). T. javanica Blume is distributed in Java, Lombok (Kalkman 
1955; Steenis 1972; Comber 1990), and also some record from Luzon, Philippine (Steenis 1972) which need further investigation.

Thelymitra has being well studied by Berhardt, Edens-Meier, and Jeanes in morphological and pollination mechanism. However, there is insufficienet taxonomical studies for species $T$. javanica, while there is concern that half of terrestrial orchid species were extinct (Swartz \& Dixon 2009) which might includes this species. T. javanica occupied specific habitat and has disjunct distribution that probably lead to its intraspecific variation both genetically or morphologically. This study was conducted to evaluate morphological variations and phenetic relationships of $T$. javanica from different ecotypes in Java. The study sites were in three mountains, i.e. Mount Arjuno (East Java), Lawu (borderline of East and Central Java), and Sumbing (Central Java).

\section{MATERIALS AND METHODS}

\section{Data Collection}

The study was conducted in three mountains: Mount Arjuno (East Java), Lawu (borderline of East and Central Java), and Sumbing (Central Java), on August 2016-August 2017 (Fig 1). T. javanica usually found in open area or under the shade of grass, eidelweis (Anaphalis spp.), cantigi (Vaccinium varingiaefolium), Casuarina junghuhniana, and various type of grass (Poaceae and $C y$ peraceae).

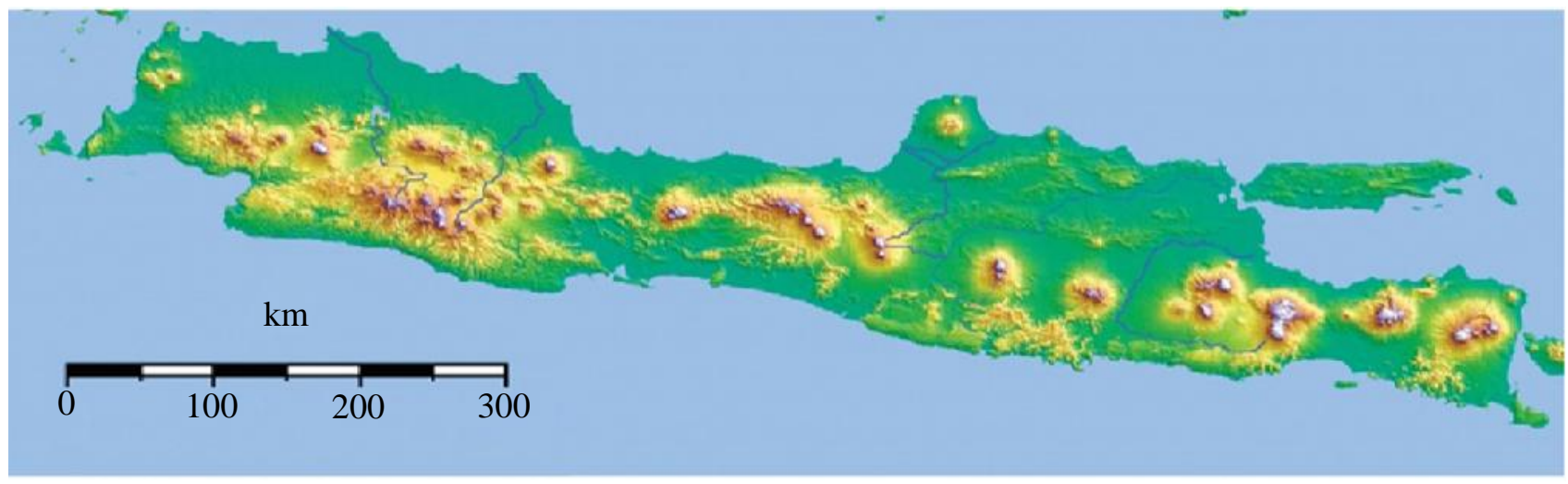

Figure 1. Study site of T. javanica in Mount Arjuno, Lawu, and Sumbing.

Randomly, choosed 3-5 populations from each mountain with different altitude as a sampling unit, and collected 1-3 individual of each population as a repetition (Table 1). Total of samples were 13, consist of 5 samples from Mount Arjuno, 5 samples from Mount Lawu, and 3 samples from Mount Sumbing. Morphological data were also collected by photo documentations (Baskauf \& Kirchoff 2008) for its habitat, whole plant, and flower including close up for column as a specific character in Thelymitra (Burns-Balogh \& Bern- hardt 1988; Jeanes 2013). The morphological description for each sampling unit following description and terminology by Averyanov (2008) and Jeanes (2013). Character observed in this study were root and tuber, leaf, peduncle, flower, fruit, and seed. The colors of every observed characters was compared to the $6^{\text {th }}$ edition Royal Horticulture Society (RHS) color chart (2015). Specimens were collected as spirit specimens and deposited in Herbarium Bogoriense, Indonesian Institute of Science (LIPI).

Table 1. Sampling units of $T$. javanica

\begin{tabular}{cccc}
\hline Mount & Sampling Unit & Altitude (m. asl.) & Code \\
\hline Arjuno & 1 & 3,026 & Arj-01 \\
Arjuno & 2 & 3,084 & Arj-02 \\
Arjuno & 3 & 3,119 & Arj-03 \\
Arjuno & 4 & 3,196 & Arj-04 \\
Arjuno & 5 & 3,323 & Arj-05 \\
Lawu & 1 & 2,478 & Lawu-01 \\
\hline
\end{tabular}


Table 1. Sampling units of $T$. javanica (continued)

\begin{tabular}{cccc}
\hline Mount & Sampling Unit & Altitude (m. asl.) & Code \\
\hline Lawu & 2 & 2,714 & Lawu-02 \\
Lawu & 3 & 2,995 & Lawu-03 \\
Lawu & 4 & 3,116 & Lawu-04 \\
Lawu & 5 & 3,243 & Lawu-05 \\
Sumbing & 1 & 3,140 & Sum-01 \\
Sumbing & 2 & 3,193 & Sum-02 \\
Sumbing & 3 & 3,201 & Sum-03 \\
\hline
\end{tabular}

\section{Data Analysis}

Morphological data were analyzed descriptively to identify the variations in character of observed organs, which completed in MVSP v.3.0 (Multivariate Statistical Package) software to construct phenetic dendrogram and for Principal Component Analysis (PCA). Dendrogram constructed by Percent Similarity algorithm and Unweighted Pair Group with Mean of Arithmetic (UPGMA) clustering method, while the PCA scattered plot was constructed using Euclidean Distance algorithm. PCA was implemented to indicate characters that contribute the most in generating distinct group. 83 morphological characters have been generated, but only 19 qualitative characters found to be sufficiently varies among sampling units (Table 2). The data set resulted from observation of 13 samples that is used for numerical analysis is presented in Table 3. Most of these characters are colors which considered as impression of plastic adaptation and is suggested to be avoided (Sokal \& Sneath 1963). However, in this study, color is viewed as an acceptable character to discriminate variation within a species compare to other observed characters, as demonstrated in the aforemention analysis.

Table 2. Morphological characters and scores of $T$. javanica

\begin{tabular}{|c|c|c|}
\hline Code & Characters & Character Scores \\
\hline K1 & Color of peduncle & $\begin{array}{l}\text { 1: green (RHS2015143A), 2: purplish pink (RHS2015076B), 3: } \\
\text { purplish red (RHS2015077B) }\end{array}$ \\
\hline $\mathrm{K} 2$ & Color of leaf base & 1: green (RHS2015143A), 2: purplish red (RHS2015077B) \\
\hline K3 & Color of leaf blade & $\begin{array}{l}\text { 1: green (RHS2015143A), 2: purplish red gradated green } \\
\text { (RHS2015077B - RHS2015139B) }\end{array}$ \\
\hline K4 & Color of leaf vein & 1: green (RHS2015143A), 2: purplish red (RHS2015077B) \\
\hline K5 & Leaf's vein clarity & 1: blurry, 2: clear \\
\hline K6 & Color of bractea & $\begin{array}{l}\text { 1: green (RHS2015143A), 2: greenish purplish red } \\
\text { (RHS2015144D), 3: purplish red (RHS2015077B) }\end{array}$ \\
\hline K7 & Color of median adaxial sepal & $\begin{array}{l}\text { 1: pale green gradated purplish pink (RHS2015146D - } \\
\text { RHS2015076B), 2: green gradated purplish red (RHS2015144D } \\
\text { - RHS2015077B), 3: purplish red (RHS2015077B) }\end{array}$ \\
\hline K8 & Color of abaxial sepal & $\begin{array}{l}\text { 1: purplish pink gradated purplish red (RHS2015076B - } \\
\text { RHS2015077B), 2: purplish red (RHS2015077B), 3: blue gra- } \\
\text { dated purplish red (RHS2015085B, RHS2015100B - } \\
\text { RHS2015077B) }\end{array}$ \\
\hline K9 & Color of petal & $\begin{array}{l}\text { 1: purplish pink gradated purplish red (RHS2015076B - } \\
\text { RHS2015077B), 2: purplish red (RHS2015077B), 3: blue gra- } \\
\text { dated purplish red (RHS2015085B, RHS2015100B - } \\
\text { RHS2015077B) }\end{array}$ \\
\hline
\end{tabular}


Table 2. Morphological characters and scores of T. javanica (continued)

\begin{tabular}{|c|c|c|}
\hline Code & Characters & Character Scores \\
\hline K10 & Color of labellum & $\begin{array}{l}\text { 1: purplish pink gradated purplish red (RHS2015076B - } \\
\text { RHS2015077B), 2: purplish red (RHS2015077B), 3: blue gra- } \\
\text { dated purplish red (RHS2015085B, RHS2015100B - } \\
\text { RHS2015077B) }\end{array}$ \\
\hline K11 & Color of column & $\begin{array}{l}\text { 1: white (RHS2015NN155C), 2: white with purplish margin } \\
\text { (RHS2015NN155C - RHS2015077B) }\end{array}$ \\
\hline K12 & $\begin{array}{l}\text { Color of the top dorsal of } \\
\text { column }\end{array}$ & $\begin{array}{l}\text { 1: brown gradate yellow (RHS2015165A - RHS2015015C), 2: } \\
\text { brownish orange (RHS2015169A) }\end{array}$ \\
\hline K13 & $\begin{array}{l}\text { Contour of the top dorsal of } \\
\text { column }\end{array}$ & 1: smooth-grooved-wide, 2 : smooth-grooved-narrow \\
\hline K14 & Color of column's wings & 1: white (RHS2015NN155C), 2: purplish white (RHS2015075C) \\
\hline K15 & Color of column's thricomes & $\begin{array}{l}\text { 1: white (RHS2015NN155C), 2: white with purplish base } \\
\text { (RHS2016075C) }\end{array}$ \\
\hline K16 & Dense of column's thricomes & 1: dense, 2: loose \\
\hline K17 & Color of pollinia & 1: white (RHS2015NN155C), 2: yellow (RHS2015161C) \\
\hline K18 & Color of ovary & $\begin{array}{l}\text { 1: green (RHS2015144B), 2: purplish green (RHS2015N77A), } 3 \\
\text { purplish red (RHS2015077B) }\end{array}$ \\
\hline K19 & Color of ovary ribs & $\begin{array}{l}\text { 1: green (RHS2015144B), 2: purplish green (RHS2015N77A), 3 } \\
\text { purplish red (RHS2015077B, RHS2015084B) }\end{array}$ \\
\hline
\end{tabular}

Table 3. Data set of $T$. javanica characters (K) and scores for numerical taxonomy analysis

\begin{tabular}{|c|c|c|c|c|c|c|c|c|c|c|c|c|c|}
\hline K / Score & $\begin{array}{c}\text { Arj- } \\
01 \\
\end{array}$ & $\begin{array}{c}\text { Arj- } \\
02 \\
\end{array}$ & $\begin{array}{c}\text { Arj- } \\
03 \\
\end{array}$ & $\begin{array}{c}\text { Arj- } \\
04 \\
\end{array}$ & $\begin{array}{c}\text { Arj- } \\
05 \\
\end{array}$ & $\begin{array}{c}\text { Lawu- } \\
01 \\
\end{array}$ & $\begin{array}{c}\text { Lawu- } \\
02 \\
\end{array}$ & $\begin{array}{c}\text { Lawu- } \\
03 \\
\end{array}$ & $\begin{array}{c}\text { Lawu- } \\
04 \\
\end{array}$ & $\begin{array}{c}\text { Lawu- } \\
05 \\
\end{array}$ & $\begin{array}{c}\text { Sum- } \\
01 \\
\end{array}$ & $\begin{array}{c}\text { Sum- } \\
02 \\
\end{array}$ & $\begin{array}{c}\text { Sum- } \\
03 \\
\end{array}$ \\
\hline $\mathrm{K} 1$ & 3 & 3 & 3 & 3 & 3 & 1 & 2 & 2 & 3 & 3 & 2 & 1 & 1 \\
\hline $\mathrm{K} 2$ & 2 & 2 & 1 & 2 & 2 & 2 & 2 & 2 & 2 & 2 & 1 & 1 & 1 \\
\hline $\mathrm{K} 3$ & 1 & 2 & 1 & 1 & 2 & 1 & 1 & 1 & 1 & 1 & 1 & 1 & 1 \\
\hline K4 & 2 & 2 & 2 & 2 & 2 & 2 & 2 & 2 & 2 & 2 & 1 & 1 & 1 \\
\hline K5 & 2 & 2 & 2 & 2 & 2 & 2 & 2 & 2 & 2 & 2 & 2 & 1 & 1 \\
\hline K6 & 2 & 3 & 2 & 3 & 3 & 2 & 2 & 2 & 3 & 2 & 2 & 1 & 1 \\
\hline K7 & 1 & 3 & 2 & 3 & 3 & 2 & 2 & 1 & 1 & 1 & 1 & 1 & 2 \\
\hline K8 & 1 & 1 & 2 & 2 & 2 & 1 & 3 & 1 & 1 & 1 & 1 & 1 & 1 \\
\hline K9 & 3 & 3 & 2 & 2 & 2 & 1 & 3 & 1 & 1 & 1 & 1 & 1 & 1 \\
\hline K10 & 3 & 3 & 2 & 2 & 2 & 1 & 3 & 1 & 1 & 1 & 1 & 1 & 1 \\
\hline K11 & 1 & 1 & 1 & 1 & 1 & 1 & 2 & 1 & 1 & 1 & 1 & 1 & 1 \\
\hline K12 & 1 & 2 & 1 & 1 & 1 & 1 & 1 & 1 & 1 & 1 & 1 & 1 & 1 \\
\hline K13 & 1 & 2 & 1 & 1 & 1 & 1 & 1 & 2 & 2 & 1 & 1 & 1 & 2 \\
\hline K14 & 2 & 2 & 1 & 2 & 2 & 1 & 1 & 1 & 1 & 1 & 2 & 2 & 2 \\
\hline K15 & 1 & 2 & 1 & 1 & 1 & 1 & 1 & 2 & 1 & 1 & 1 & 1 & 1 \\
\hline K16 & 1 & 1 & 1 & 1 & 1 & 2 & 2 & 1 & 1 & 1 & 1 & 1 & 1 \\
\hline K17 & 1 & 1 & 2 & 2 & 1 & 1 & 1 & 2 & 1 & 1 & 1 & 1 & 1 \\
\hline K18 & 1 & 1 & 3 & 3 & 3 & 1 & 1 & 2 & 2 & 2 & 1 & 1 & 1 \\
\hline K19 & 3 & 3 & 3 & 3 & 3 & 1 & 1 & 2 & 2 & 2 & 1 & 1 & 1 \\
\hline
\end{tabular}




\section{RESULTS AND DISCUSSION}

\section{RESULTS}

The present the study results in two section, i.e. morphological variations and phenetic analyses of $T$. javanica.

\section{A. Morphological Variations of T. javanica in study site}

\section{Root and tuber variations}

Morphological variations were observed for vegetative and generative organs, including root and tuber. Both characters in T. javanica is varies in size and number. Root is generally cylindrical, thick, light brown (RHS2015164C, RHS20151 64D), and attached at the base of tuber. Tuber has oblanceolate shape and its number ranged 1-3 tubers in each plant.

\section{Leaf variations}

T. javanica has one linear leaf, conduplicate, entire margin, acute apex, and size 9.6-22.0 x 0.5$0.7 \mathrm{~cm}$. Variations occur in the color of leaf blade, leaf base, and veins consist of green (RHS2015 143A) and purplish red (RHS2015077B). The bractea of $T$. javanica has lanceolate shape, entire margin, and acute apex. The color variations in this organ are green (RHS2015143A, RHS2015144D), purplish green (RHS2015144D-RHS2015077B), and purplish red (RHS2015077B).

\section{Inflorescence variations}

The type of inflorescence is raceme, 9.1$29.1 \mathrm{~cm}$ long, 2-10 flowers, thick and generally has thin white layer (cuticule). The color variation are green (RHS2015143B), purplish pink (RHS 2015076B), and purplish red (RHS2015077B, RHS2015N77A).

\section{Flower variations}

Sepal of $T$. javanica has narrowly-ovate shape, $1.2-2.2 \times 0.4-0.8 \mathrm{~cm}$, entire margin, and acute apex. The abaxial color is varied from purplish pink gradated to purplish red (RHS2015076B -RHS2015077B), purplish red (RHS2015077B), or blue gradated to purplish red (RHS2015085B, RHS2015100B-RHS2015076B). The adaxial part has the same color as its abaxial, but has additional color on the median part which is pale green gradated to purplish pink (RHS2015146D-RHS2015 076B), green gradated to purplish red (RHS2015 144D-RHS2015077B), and purplish red (RHS2015 077B) (Fig. 2). The purplish red sepal only found in Mount Arjuno's specimens.

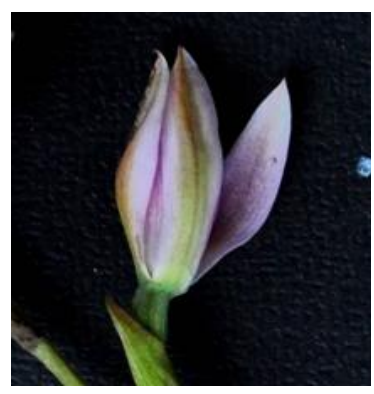

(a)

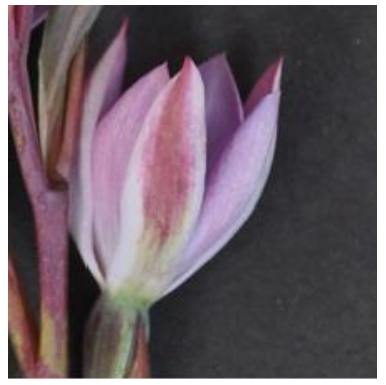

(b)

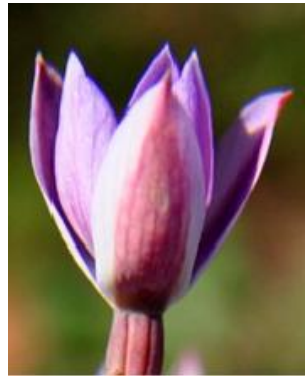

(c)

Figure 2. Median sepal variations of T. javanica (a). Green gradated to purplish red in Mount Sumbing; (b). Pale green gradated to purplish pink in Mount Lawu; and (c). Purplish red in Mount Arjuno.

Petal has narrowly-ovate shape, 1.1-1.8 x $0.5-1.0 \mathrm{~cm}$, entire margin, and acute apex. Labellum has the same characteristics, except on the size that narrower than petal, about $1.0-1.9 \times 0.4-0.6$ $\mathrm{cm}$. The color variations are purplish pink gradated to purplish red (RHS2015076B-RHS2015077B), purplish red (RHS2015077B), or blue gradated to purplish red (RHS2015085B, RHS2015100BRHS2015076B) (Fig. 3a-c). Flower of lower altitude ( $\pm 100 \mathrm{~m}$ asl.) plants shows white perianthium when blooming (Fig. 3d).

There are variation in column of $T$. javani$c a$. The column's wing has white (RHS2015 NN155C) or purplish white (RHS2015075C) color, while the top dorsal of column has brown gradate to yellow (RHS2015165A-RHS2015015C), brownish orange (RHS2015169A), or yellow (RH S2015015C) for plant in lower altitude (Fig. 3e-g). Apex of the top dorsal of column forming a wide or narrow hole with a central groove (Fig. 3h-i). 
The column's trichomes below the top dorsal of column devided into two groups with color variation in white (RHS2015NN155C) or white with purplish base (RHS2015NN155C-RHS2015075C). The distance between the two groups of trichomes might be fairly wide or narrower (Fig. 3i-j, pointed

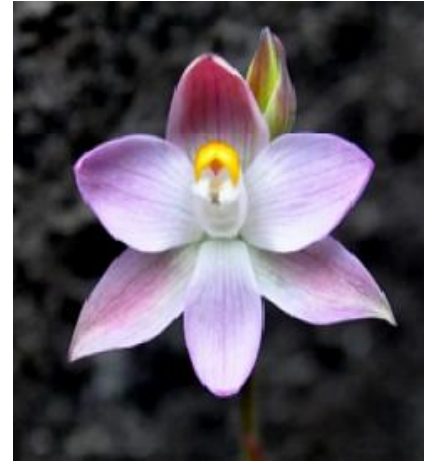

(a)

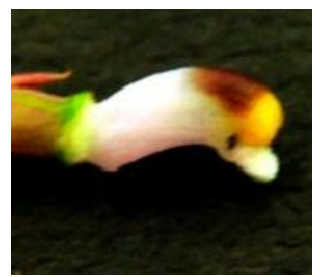

(e)

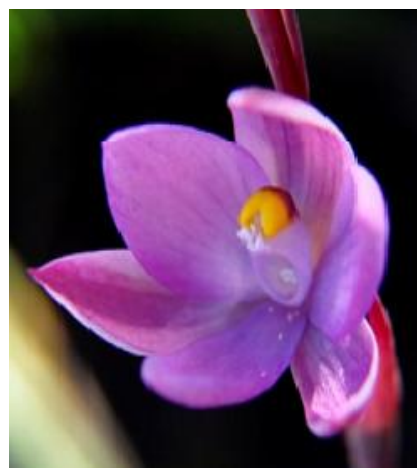

(b) by red arrow). Column has white (RHS2015NN 155C) or white with purple margin color (RHS 2015NN155C-RHS2015077B), 0.4-0.6 x 0.2-0.3 $\mathrm{cm}$, stigma cavity $0.2-0.4 \times 0.1-0.3 \mathrm{~cm}$, two pairs of pollinia in white (RHS2015NN155C) or yellow color (RHS2015161C).

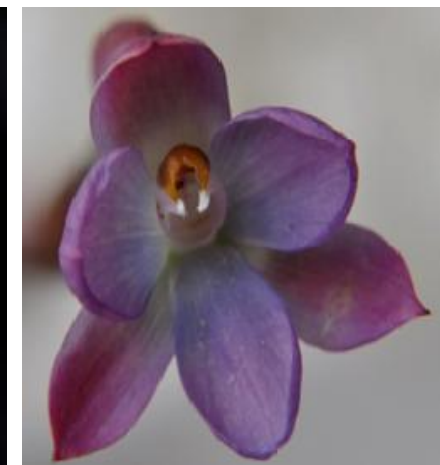

(c)

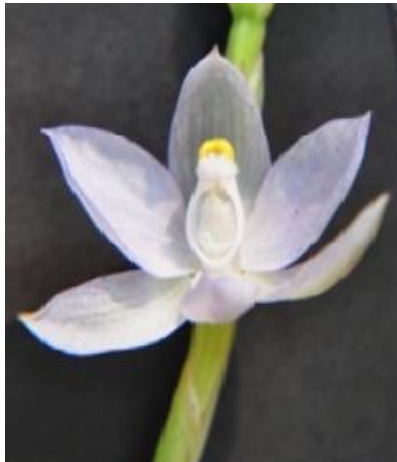

(d)

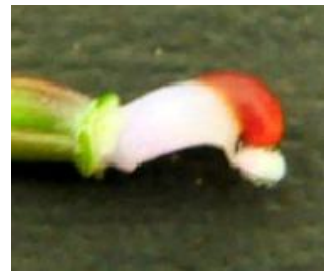

(f)

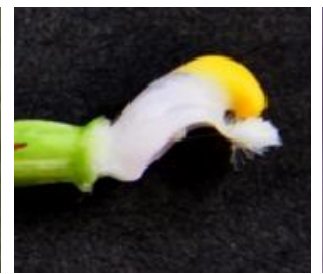

$(\mathrm{g})$

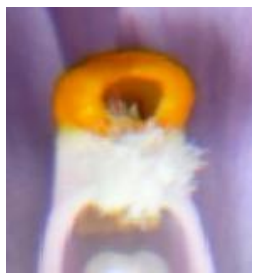

(h)

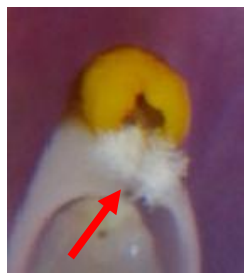

(i)

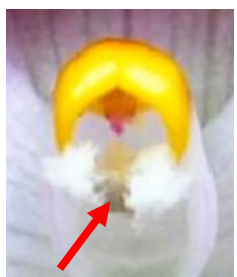

(j)

Figure 3. The flower variations of T. javanica (a). Petal and labellum with purplish pink gradated to purplish red color in Mount Lawu; (b). Petal and labellum with purplish red color in Mount Arjuno; (c). Petal and labellum with blue gradated to purplish red color in Mount Lawu; (d). Petal and labellum with white color at lower altitude; (e). The top dorsal of column in Mount Arjuno: brown gradated to yellow, and (f). brownish orange; (g). The top dorsal of column at lower altitude: yellow; (h). the top dorsal of column's hole in Mount Arjuno: wide; (i). the top dorsal of column's hole: narrow, with dense trichomes (red arrow) in Mount Lawu; (j). Loose trichomes (red arrow) in Mount Lawu.

\section{Fruit and seed variations}

The fruit was oblong in shape with ovary color in green (RHS2015144B), green with purplish red ribs (RHS2015147B-RHS2015084B), purplish green (RHS2015N77A), or purplish red (RHS2015077B) (Fig. 4a-d). The seed is bottle- shaped, testa formed by rectangular cells that covers the oval embrio with brown color (RHS2015 164C) (Fig. 4e-h). The seed size varies between $253.69 \mu \mathrm{m}$ to $443.98 \mu \mathrm{m}$, while the embrio 149.12 $\mu \mathrm{m}$ to $253.39 \mu \mathrm{m}$. The seed/embrio ratio ranged $1.59-2.31$, but commonly around 2.0 .

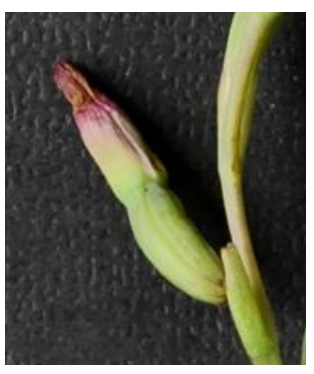

(a)

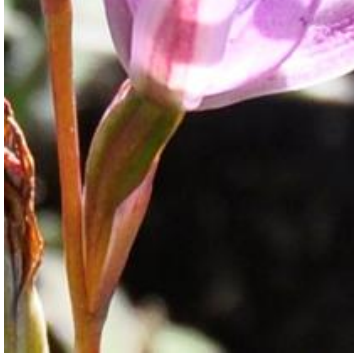

(b)

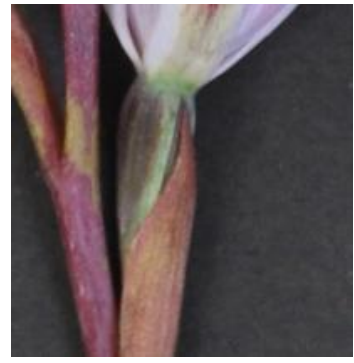

(c)

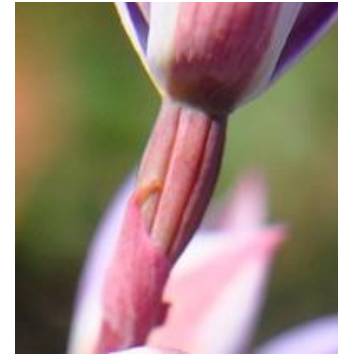

(d) 


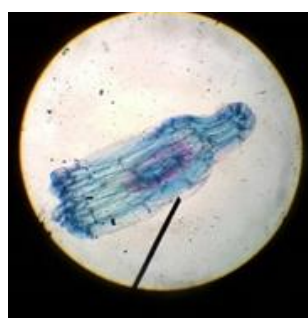

(e)

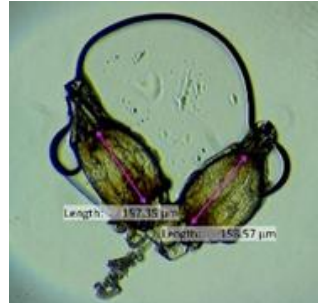

(f)

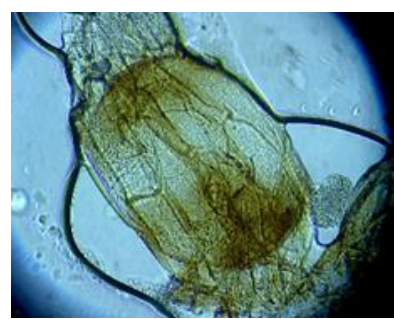

$(\mathrm{g})$

Figure 4. Fruit and seed variations of T. javanica (a). Green ovary from Mount Lawu; (b). Green with purplish red ribs ovary from Mount Arjuno; (c). Purplish green ovary from Mount Lawu; (d). Purplish red ovary from Mount Arjuno; (e). Bottle-shaped seed with oval embrio in 4x magnification with toluidine blue dye; (f). Seed with embrio sizing in Mount Arjuno, 10x magnification; and (g). The embrio of seed from Mount Arjuno, 40x magnification.

\section{B. Phenetic Relationship of $T$. javanica based on Morphological Characters}

The phenetic relationship of $T$. javanica using 19 characters and 13 sampling unit that consist of 5 from Mount Arjuno (code: Arj), 5 from Mount Lawu (code: Lawu), and 3 from Mount Sumbing (code: Sum). The dendrogram that has been constructed showing two clusters at the phenon line of $80 \%$ similarity (Fig. 5). The cluster 1 composed by all sampling unit from Mount Sumbing and Lawu, except Lawu-02 that merged with sampling units from Mount Arjuno in cluster 2.

With phenon line at $85 \%$ similarity, cluster 1 divided into two subcluster, i.e. subcluster a (Lawu -01, Lawu-03, Lawu-04, and Lawu-05) and subcluster b (Sum-01, Sum-02, and Sum-03). In cluster 2, all sampling units from Mount Arjuno (Arj01, Arj-02, Arj-03, Arj-04, and Arj-05) located in subcluster d, leaving Lawu-02 alone in subcluster c.

PCA result in Fig. 6 shows that there are 3 main clusters and one separating cluster consist only Lawu-02. This departing group of Lawu-02 is similar to the discussed dendrogram. The three main clustering resulted from PCA also in line with the dendrogram.

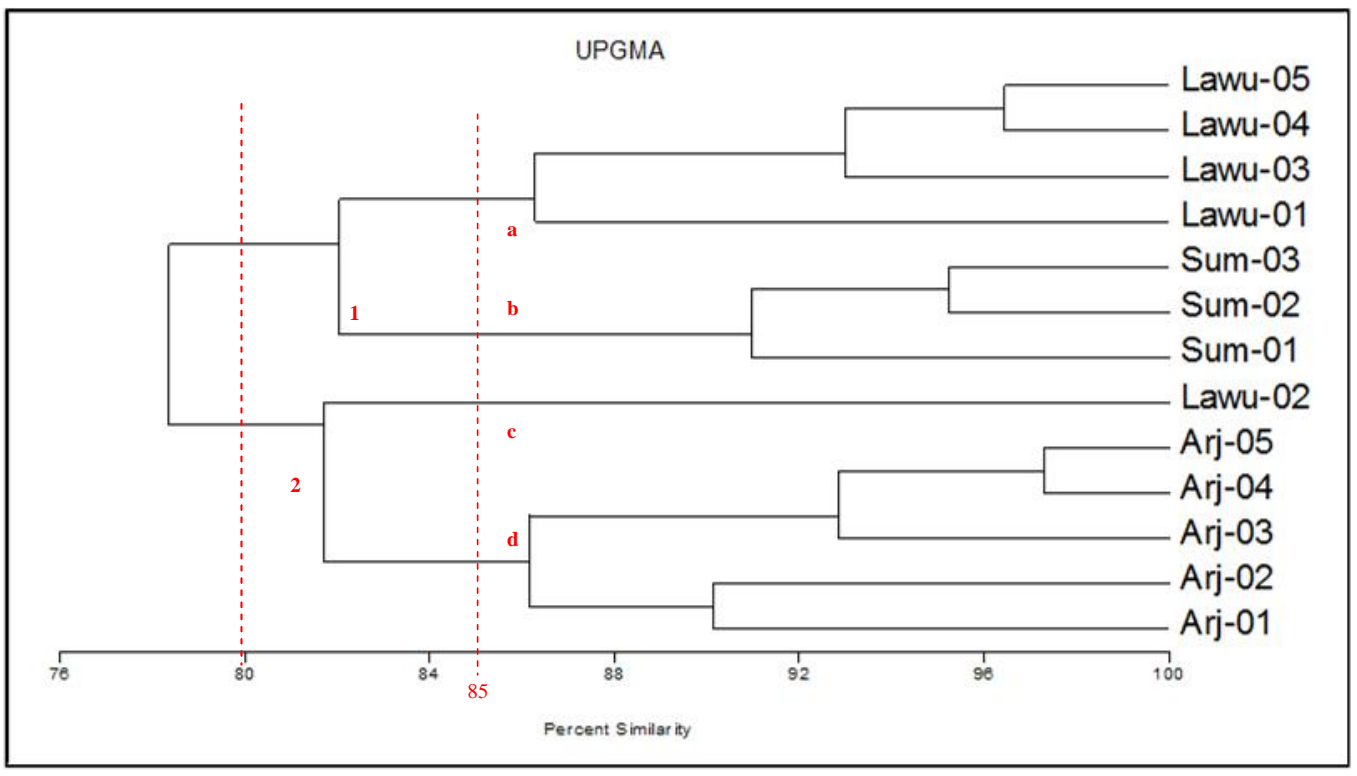

Figure 5. Dendrogram that showing phenetic relationship of $T$. javanica based on morphological characteristic in Mount Arjuno, Lawu, and Sumbing.

Note: Arj $=$ Mount Arjuno $;$ Lawu $=$ Mount Lawu $;$ Sum $=$ Mount Sumbing 


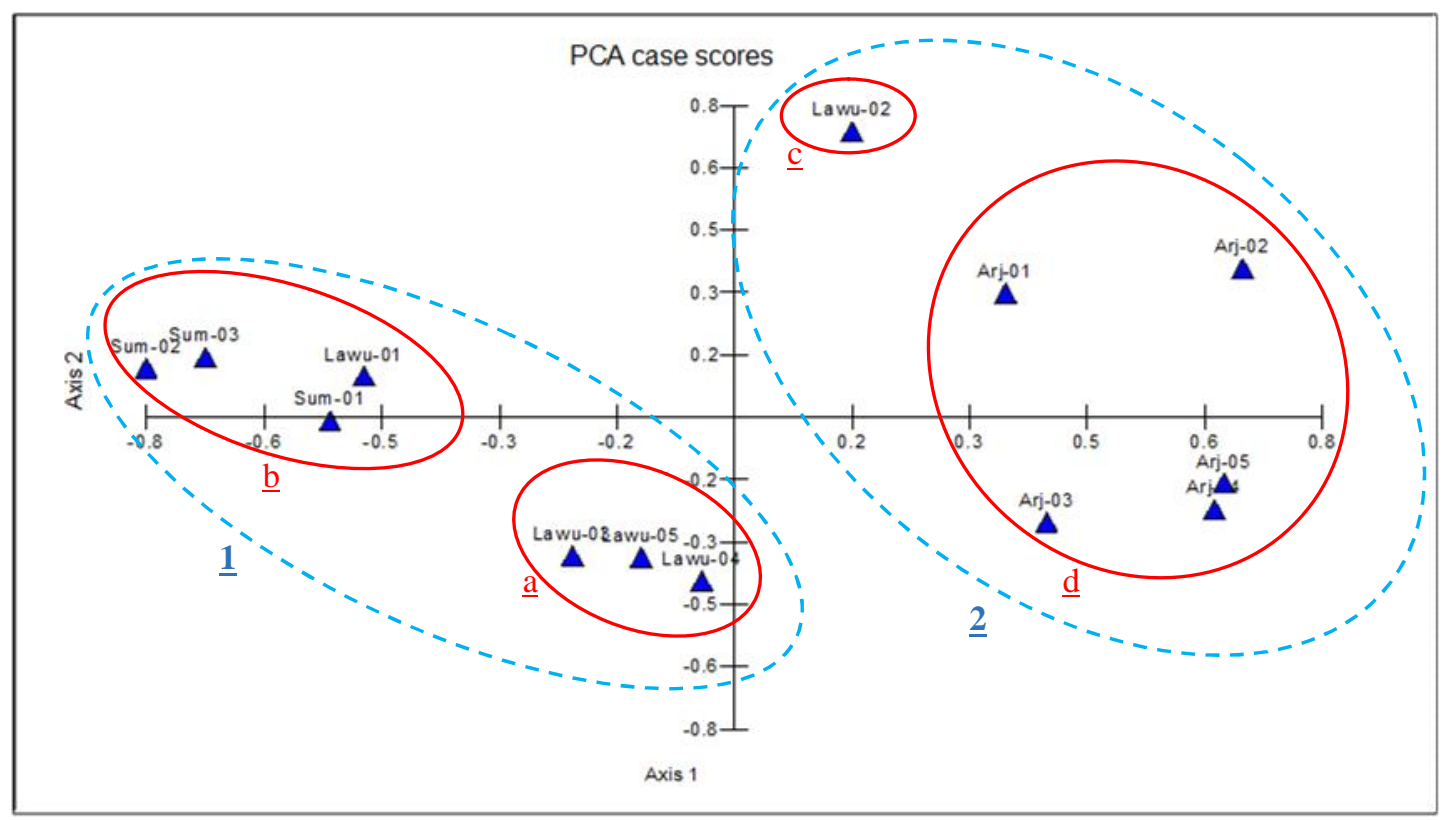

(a)

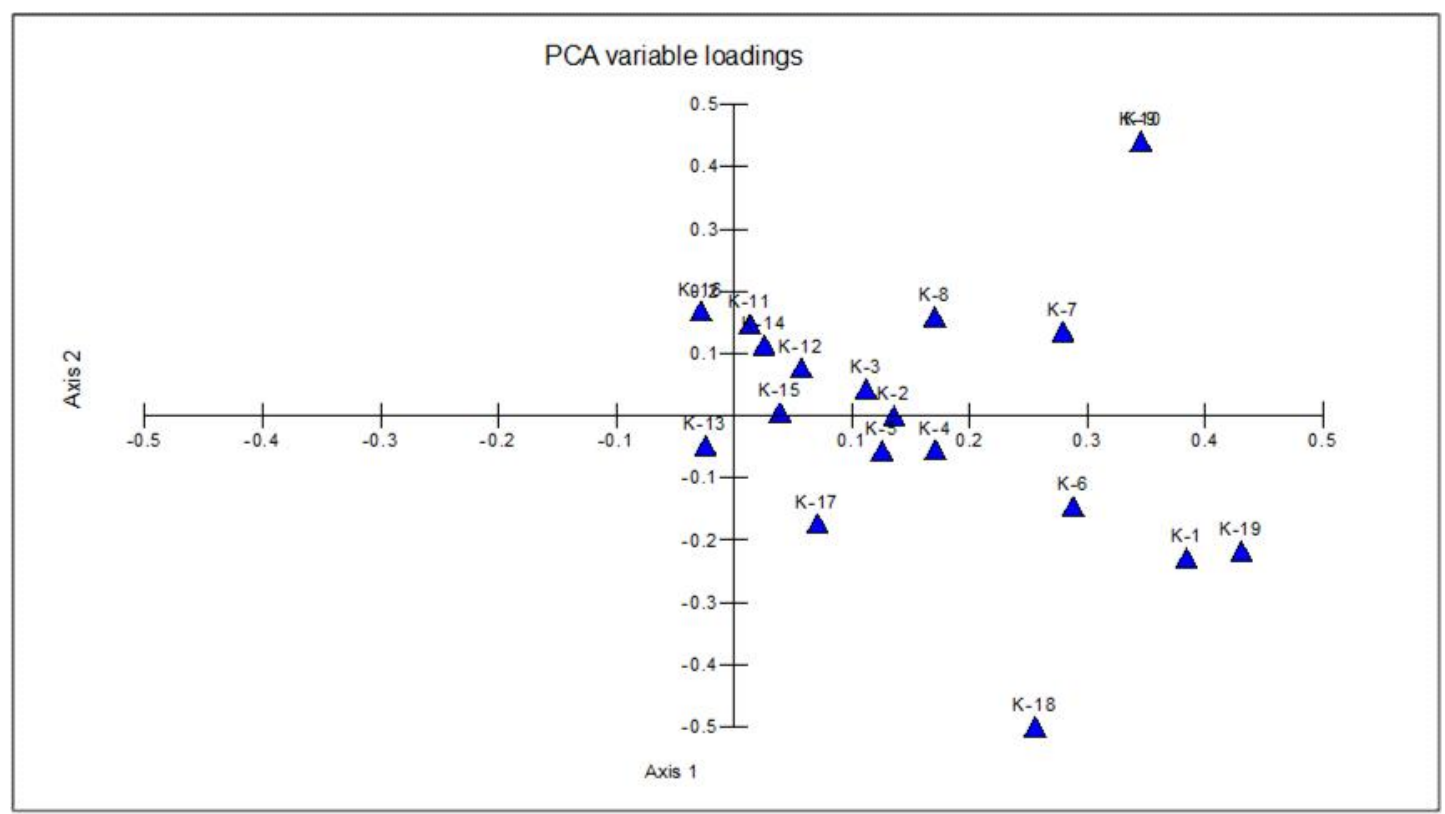

(b)

Figure 6. PCA scattered plot by Euclidean distance algorithm for phenetic relationship of $T$. javanica based on morphological characteristic in Mount Arjuno, Lawu, and Sumbing (a). Sampling units' ordination that forming cluster; and (b). Character distribution that responsible for cluster forming.

Note: Arj = Mount Arjuno; Lawu = Mount Lawu; Sum = Mount Sumbing

The cluster separation in PCA is primarily caused by morphological character with code K-1, K-9, K-10, K-18, and K-19. Those characters has the longest vector (distance) that indicate its higher impact in cluster formations. The distance is measured from the center point $(0,0)$ to the characters' code. The eigenvalues also confirmed that those characters are forming two orientations, to the Axis
1 and Axis 2. K-1 is a code for peduncle's color, $\mathrm{K}$ -9 for petal's color, K-10 for labellum's color, K18 for ovary's color, and K-19 for ovary ribs' color. K-6 and K-7 are codes for bractea's color and median adaxial sepal's color, that also showing higher eigenvalue more than 0.2 , but those are only partialy impacting ordination, i.e. for Axis 1 . 


\section{DISCUSSION}

\section{Morphological Variations of $T$. javanica}

Morphological variations of $T$. javanica is dominated by generative organ. This is shown in variability of color. Most of $T$. javanica perianthium has purplish red color while flower of individuals in lowland ( $\pm 100 \mathrm{~m}$. asl.) exhibit white color that could be caused by flavon and flavonol (Saito et al. 2007; Daniel 2009). This color variation demonstrate character plasticity that once used to classified population as ecophene or plastodeme, populations that genotypically similar but different phenotypically (Stace 1989).

\section{Phenetic Relationship of $T$. javanica based on Morphological Characters}

Phenetic dendrogram shows that the similarity of OTUs from Mount Arjuno and Sumbing has some relation with altitude. In Mount Arjuno, OTU Arj-01 and Arj-02 (joined at $90.14 \%$ similarity) collected from the lowest altitude (3,026 and $3,084 \mathrm{~m}$. asl.), was growing under the shading of C. junghuhniana and among grasses. OTU Arj-04 and Arj-05 (with highest similarity, $97.30 \%$ ) was growing near the peak, at altitude 3,196 and 3,323 $\mathrm{m}$. asl respectively, in the open area or under the shading of eidelweiss plant (Anaphalis spp.) and cantigi ( $V$. varingiaefolium).

In Mount Sumbing, although the three OTUs were collected at different altitude $(3.140,3.193$, and $3.201 \mathrm{~m}$ asl) they still grew in same identical habitat which is on the rock in savana Segara Banjaran. Furthermore, the response for the environ- mental variations were identic and showing high similarity (all at 90,96\%, and Sum-02 and Sum-03 at $95.24 \%$ ) that confirm the character plasticity by environmental adaptations (Stace 1989).

The analysis also shows that OTU Lawu-02 is more similar to OTUs from Mount Arjuno than other unit from Mount Lawu, although the similarity level was $81.71 \%$. The separation is still unexplained. Similar split also found in OTU Lawu02 that appear to have closer relationship with OTUs from Mount Sumbing.

The cluster formation by altitude as shown in this study confirmed that morphological variations observed were plastic, as a result of environmental adaptation (Elzinga et al. 2007). The pigment anthocyanin produced by this plant seems to be increasing with the higher altitude (ChalkerScott 1999; Saito et al. 2007; Daniel 2009; Ramakrishna \& Ravishankar 2011). This study also showed there are site-specific coloration occurred in different mountains. Mountain might have several ecotypes, showing character plasticity that is caused by altitude. This merit further investigation with more advance method such as molecular approaches.

Color is generally considered as high-risk character to base classification for it might resulted from environmental adaptation and hence thought as a plastic character. The case in T. javanica indicates this, color variation emerges as the respons of environmental variability. However, since every mountain shows distinct plastic characters, this could be used in differentiating separated population. The key to population is as follow:

1.a. Leaf base's color and nerve's color in purplish red 2

b. Leaf base's color and nerve's color in green T. javanica Sumbing

2.a. Petal and labellum in purplish red or blue gradated purplish red, ovary ribs' color in purplish red T. javanica Arjuno

b. Petal and labellum in purplish pink gradated purplish red (rarely blue gradated purplish red), ovary ribs' color in green or purplish green T. javanica Lawu

\section{CONCLUSION}

As the only species from the genus Thelymitra from Indonesia, T. javanica is found to have morphological plasticity for sizes and colors, especially the colors of peduncle, petal, labellum, ovarium, and ovary ribs. Based on this research, there are three groups of ecotype plasticity (plastodeme) identified: Arjuno, Lawu, and Sumbing.

\section{ACKNOWLEDGEMENT}

Thanks to Kementerian Pendidikan dan Kebudayaan (Ministry of Education and Culture) Indonesia for the funding through "Beasiswa Unggulan" program, Faculty of Biology Universitas Gadjah Mada for the funding by program "Penelitian Biodiversitas Tropika Dosen untuk Pengembangan Materi Pembelajaran" from BPTTNbh 2017 with contract number UGM/BI/1766/UM/05/01, Lembaga Ilmu Pengetahuan Indonesia (LIPI), members 
of Ekspedisi NKRI 2014 and Biology Orchid Study Club (BiOSC) Faculty of Biology Universitas Gadjah Mada.

\section{REFERENCES}

Averyanov L. 2008. The Orchid of Vietnam Illustrated Survey Part 1: Subfamilies Apostasioideae, Cypripedioideae and Spiranthoideae. Turczaninowia 11(1): 5-168

Backer CA \& Bakhuizen v.d. Brink RCB. 1968. Flora of Java (spermatophytes only) vol. III. Wolters Noordhoff N.V. Groningen: Netherlands. p. 254.

Baskauf SJ \& Kirchoff BK. 2008. Digital Plant Images as Specimens: Forward Standards for Photographic Living Plants. Vulpia 7: 16 -30 .

Brown A, Dundas P, Dixon K \& Hopper S. 2008. Orchids of Western Australia. University of Western Australia Press. Australia. Pp: 113.

Burns-Balogh P \& Bernhardt P. 1988. Floral evolution and phylogeny in Tribe Thelymitreae (Orchidaceae: Neottioideae). Pl. Sys. Evol. 159: 19-47

Chalker-Scott L. 1999. Environmental significance of anthocyanins in plant stress responses. Phytochemistry and Photobiology 70(1): 19.

Comber JB. 1990. Orchids of Java. Royal Botanical Garden: Kew.

Daniel M. 2009. Taxonomy: Evolution at work. Narosa Publishing House: New Delhi. Pp. 81-85, 520-521.

Dressler RL. 1993. Phylogeny and Classification of the Orchid Family. Cambridge University Press: Cambridge.

Edens-Meier R, Westhus E \& Bernhardt P. 2013. Floral biology of large-flowered Thelymitra species (Orchidaceae) and their hybrids in Western Australia. Telopea Journal of Plant Sistematics 15: 165-183.

Edens-Meier R \& Bernhardt P. 2014. Darwin's Orchid: Then and Now. University of Chicago Press: Chicago. Pp. 173-197.
Elzinga JA, Atlan A, Biere A, Gigord L, Weis AE \& Bernasconi G. 2007. Time after time: Flowering phenology and biotic interactions. Trends in Ecology and Evolution 22(8): 432 -437 ,

Jeanes JA. 2013. An overview of Thelymitra nuda (Orchidaceae) complex in Australia including the description of six new species. Muelleria 31: 3-30.

Kalkman C. 1955. A plant-geographical analysis of the Lesser Sunda Islands. Acta Botanica Neerlandica 4(2): 200-225.

Kindlmann P \& Jersakova J. 2005. Floral display, reproductive success, and conservation of terrestrial orchids. Selbyana 26(1,2): 136144.

Myers N, Mittermeier RA, Mittermeier CG, da Fonseca GAB \& Kent L. 2000. Biodiversity hotspots for conservation priorities. Nature 403: 853-858.

Ramakrishna A \& Ravishankar GA. 2011. Influences of abiotic signals on secondary metabolites in plants. Plant Signaling and Behavior 6(11): 1720-1731.

Roberts DL \& Dixon KW. 2008. Orchids. Current Biology 18(8): 325-329.

Royal Horticultural Society. 2015. Colour Chart $6^{\text {th }}$ ed. RHS: UK.

Saito R, Kuchitsu K, Ozeki Y \& Nakayama M. 2007. Spatiotemporal metabolic regulation of anthocyanin and related compounds during the development of marginal Picotee petals in Petunia hybrid (Solanaceae). J. Plant Res. 120: 563-568.

Sokal RR \& Sneath PHA. 1963. Principles of Numerical Taxonomy. W.H. Freeman and Company: USA.

Stace CA. 1989. Plant Taxonomy and Biosystematics $2^{\text {nd }} e d$. Routledge, Chapman and Hall Inc.: New York. Pp. 11-16, 192-194.

Steenis van CGGJ. 1972. The Mountain Flora of Java. Leiden. E.J. Brill.

Swarts ND \& Dixon KW. 2009. Terrestrial Orchid Conservation in the Age of Extinction. Annals of Botany 104: 543-556. 